\title{
Effects of Ipomoea aquatica Forsk. in cyclophosphamide induced dyslipidaemia in albino rats
}

\author{
Rajesh Das ${ }^{1 *}$, Khuraijam Sucheta Devi², Sayeri Dutta ${ }^{1}$, Ananya Das ${ }^{1}$, Prasenjit Das ${ }^{2}$, \\ Kh Krishna Pramodini Devi ${ }^{1}$
}

${ }^{1}$ Department of Pharmacology, ${ }^{2}$ Department of Pathology, RIMS, Imphal, Manipur, India

Received: 16 August 2017

Accepted: 21 September 2017

\section{*Correspondence to:}

Dr. Rajesh Das,

Email: drrajeshdas85@

gmail.com

Copyright: (C) the author(s), publisher and licensee Medip Academy. This is an openaccess article distributed under the terms of the Creative Commons Attribution NonCommercial License, which permits unrestricted noncommercial use, distribution, and reproduction in any medium, provided the original work is properly cited.

\begin{abstract}
Background: Cyclophosphamide (CP) is commonly used as anticancer and immuno suppressant agent. It induces hyperlipidemia and myocardium damage. Ipomoea aquatic Forsk. is traditionally used for cardiovascular disease, paralysis and general debility. The present study was done to evaluate the protective effect of the plant against $\mathrm{CP}$ induced dyslipidaemia in albino rats.

Methods: Twenty albino rats were divided into 4 groups of 5 animals each. Group I (normal group) received normal saline intraperitoneally. Groups II to IV received CP $(200 \mathrm{mg} / \mathrm{kg}$ body weight, intraperitoneally) single dose on day 1 of experimental period. Groups I and II (toxic group) animals were given $2 \%$ gum acacia per orally daily for 10 days. Groups III and IV received aqueous extract of stem and leaves of Ipomoea aquatica $200 \mathrm{mg} / \mathrm{kg}$ and $400 \mathrm{mg} / \mathrm{kg}$ per orally respectively daily for 10 days. On 11 th day, blood samples were collected for estimation of triglycerides, total cholesterol, LDL-cholesterol and HDLcholesterol and heart tissues were sent for histopathology examination (HPE).

Results: CP administration significantly $(\mathrm{P}<0.05)$ increased the levels of triglyceride, total cholesterol, LDL-cholesterol and decreased the level of HDLcholesterol in toxic group compared to normal group. Treatment with aqueous extract of Ipomoea aquatica significantly $(\mathrm{P}<0.05)$ reversed the status of lipid profile compared to toxic group. HPE of myocardium showed reversal of the toxic effects of CP in the extract treated groups.

Conclusions: Ipomoea aquatica showed protective effects against CP induced dyslipidaemia in albino rats.
\end{abstract}

Keywords: Albino rats, Cyclophosphamide, Dyslipidaemia, Ipomoea aquatic Forsk.

\section{INTRODUCTION}

Cyclophosphamide (CP) is one of the most widely used alkylating agents. It can be administered orally and intravenously. It is mainly used for breast cancer, ovarian cancer, non-Hodgkin's lymphoma, chronic lymphocytic leukemia, soft tissue sarcoma, neuroblastoma, Wilms' tumor, rhabdomyosarcoma and as immunosuppressant agent. It is activated by hepatic cytochrome $\mathrm{P} 450$ mixedfunction oxidase system and converted to 4hydroxycyclophosphamide, which is in equilibrium with aldophosphamide. Aldophosphamide, delivered to both tumour and normal tissue is converted to cytotoxic form phosphoramide mustard and acrolein by nonenzymatically. ${ }^{1}$

Acrolein damages many cell types by producing reactive oxygen species and lipid peroxidation. Oxidative stress is associated with the pathogenesis of cardiovascular disorder including ischemic heart disease, heart failure and atherosclerosis. Acrolein also decreases cholesterol clearance by reducing hepatic lipase activity. Reduced cholesterol clearance is associated with dyslipidemia. Acrolein induced dyslipidemia is characterized by changes 
in the lipoprotein composition especially in VLDL cholesterol and triglycerides and induces pro-atherogenic changes in lipoproteins. It was found that, acrolein can induce apoptosis by activation of the mitochondrial pathway or death receptor signalling. In some studies, it was proved that acrolein can exerts detrimental effects in adult mice heart tissues through apoptotic cell death. ${ }^{2,3}$

Ipomoea aquatica Forsk. belongs to the family Convolvulaceae. It is commonly known as Water spinach, Kolamani (Manipuri), Kalmisak (Bengali) etc. This plant has a wide distribution and grows in moist soils, side-lines of fresh water, ditches, lakes, ponds, marshes and wet rice field usually all-round the year. The plant is commonly found in Manipur, Bihar, Orissa, Bengal and South India. It is generally consumed as vegetable. ${ }^{4,5}$ Ipomoea aquatica is traditionally used for cardiovascular disease, paralysis, general debility and as purgative. Juice of plant is use for ring worm (with salt), opium and arsenic poisoning. Leaves of plant relieve pain due to insect bites. ${ }^{6}$

The non-toxic nature of Ipomoea aquatica as well as its multiple beneficial effects has made it one of the most attractive compounds to explore for its protective role. Therefore, the present attempt has been made to investigate its role in dyslipidaemia induced by cyclophosphamide.

\section{METHODS}

\section{Chemicals and reagents}

Cyclophosphamide (CYPHOS ${ }^{\mathrm{TM}}$ ) was purchased from Getwell Pharmaceuticals, Haryana, India. Biochemical estimation kits (BenespheraS ${ }^{\mathrm{TM}}$ ) were obtained from Avantor Performance Materials India Ltd, Uttarakhand. Other chemicals and solvents used were of highest purity and analytical grade.

\section{Study Setting}

The study was conducted at Department of Pharmacology and Department of Pathology, Regional Institute of Medical Sciences (RIMS), Imphal, Manipur, India.

\section{Preparation of aqueous extract of Ipomoea aquatica Frosk.}

The fresh plant of Ipomoea aquatica was collected from local market in the month of October, 2016. They were identified and authenticated by Professor P. K. Singh of the Life Sciences Department, Manipur University, Imphal, India. The leaves and stems were separated, cleansed with water, cut into small pieces and dried in shade. It was then coarsely powdered by mixer grinder. Aqueous extract of Ipomoea aquatica (AEIA) was prepared by soxhlet extraction method described by Verma SCL and Agrawal SL. ${ }^{7}$ Brownish crude dry extract was obtained. The yield was $19.5 \%$. The extract was freshly dissolved in $2 \%$ gum acacia before giving each dose to animals.

\section{Acute oral toxicity study}

For acute oral toxicity study, Limit test was done in albino rats according to OECD guideline 423. Rats were healthy and there was no mortality observed at the dose of $2000 \mathrm{mg} / \mathrm{kg}$ till 14 days. So, doses were selected $200 \mathrm{mg} / \mathrm{kg}$ and $400 \mathrm{mg} / \mathrm{kg}$ for the study. ${ }^{8}$

\section{Experimental animals}

Healthy adult albino wistar rats of either sex weighing 110$210 \mathrm{gm}$ were housed in standard polypropylene cages, maintained under controlled room temperature $\left(21^{\circ} \pm 2^{\circ} \mathrm{C}\right)$, relative humidity $(55 \pm 5 \%)$ and under $12: 12 \mathrm{~h}$ artificial light and dark cycle in the well-ventilated animal house, Department of Pharmacology, RIMS, Imphal. Animals were acclimatized for five days. All the rats were provided with commercially available standard pellet diet, water ad libitum. The animals were maintained under standard conditions in the animal house as per the guidelines of Committee for the Purpose of Control and Supervision on Experiments on Animals (CPCSEA). ${ }^{9}$

\section{Experimental protocol}

The animals comprising 20 albino rats were divided into four groups, five animals each. Group I served as normal control receiving single intraperitoneal (i.p.) injection of $0.5 \mathrm{ml} / 100 \mathrm{gm}$ of $0.9 \%$ normal saline. Groups II, III and IV received one dose of $\mathrm{CP}(200 \mathrm{mg} / \mathrm{kg}$ body weight) dissolved in $0.9 \%$ normal saline through i.p. injection on day 1 . Groups I and II received $2 \%$ gum acacia suspension (1ml/100gm, per orally daily for 10 days). Groups III and IV were received $200 \mathrm{mg} / \mathrm{kg}$ and $400 \mathrm{mg} / \mathrm{kg}$ of AEIA ( $1 \mathrm{ml} / 100 \mathrm{gm}$, per orally daily for 10 days) dissolved in $2 \%$ gum acacia. Group II served as CP control group.

\section{Serum lipid profile estimation}

Blood samples were collected on $11^{\text {th }}$ day from retroorbital venous sinus by using capillary tube under ether anaesthesia. Serum was separated by centrifugation at $3000 \mathrm{rpm}$ for $10 \mathrm{mins}$ and used in biochemical estimation of triglycerides (TG), total cholesterol (TC) and HDLcholesterol (HDL-c). Serum estimation of triglyceride was done as per Sullivan DR et al, total cholesterol was done as per Allian CC et al, HDL-cholesterol was done as per Grub F et al, method. ${ }^{10-12}$ Direct colorimetric method was used for these methods. LDL-cholesterol (LDL-c) was calculated by using Friedwald and Fredrickson's formula LDL-c $=$ Total cholesterol $-($ Triglyceride $/ 5+$ HDL-c $) .{ }^{13}$

\section{Atherogenic index (AI) values}

AI or cardiac risk ratio was calculated by using formula $\mathrm{AI}=$ total cholesterol/HDL-cholesterol. Percentage of protection was calculated by [(AI of toxic control group- 
AI of extract treated group)/AI of toxic control group] $\times 100 .{ }^{14}$

\section{Histopathological evaluation}

After blood collection, all the animals were sacrificed with high dose ether. A midline incision was performed at the thoracic region. The heart was dissected out, fixed in $10 \%$ formalin for approximately 48 hours. The paraffin sections were prepared on a glass slide and stained with haematoxylin and eosin for subsequent microscopic evaluation. $^{15-17}$

\section{Statistical analysis}

Data was computed in SPSS version 21 software. Results were expressed as mean \pm SEM. One-way analysis of variance (ANOVA) followed by Dunnett's-t test was used for comparisons between different groups. $\mathrm{P}$ value $<0.05$ was considered to be significant.

\section{RESULTS}

\section{Effects on lipid profile}

$\mathrm{CP}$ control group demonstrated a significant $(\mathrm{P}<0.05)$ increase in serum levels of TG, TC, LDL-c and decrease in serum level of HDL-c compared to normal control group. Treatment with Ipomoea aquatica (AEIA $200 \mathrm{mg} / \mathrm{kg}$ and $400 \mathrm{mg} / \mathrm{kg}$ ), after inducing toxicity by CP there was significant $(\mathrm{P}<0.05)$ decrease in the levels of serum TG, TC, LDL-c and increase in the levels of serum HDL-c compared to CP control group (Table 1).

Table 1: Effect of Ipomoea aquatica on serum level of lipid profile in CP-induced dyslipidaemia in rats.

\begin{tabular}{|lllll|}
\hline Group & $\begin{array}{l}\text { Triglyceride } \\
(\mathbf{m g} / \mathbf{d L})\end{array}$ & $\begin{array}{l}\text { Total cholesterol } \\
(\mathrm{mg} / \mathrm{dL})\end{array}$ & $\begin{array}{l}\text { LDL-cholesterol } \\
\text { (mg/dL) }\end{array}$ & $\begin{array}{l}\text { HDL-cholesterol } \\
(\mathbf{m g} / \mathbf{d L})\end{array}$ \\
\hline Normal control & $59.30 \pm 3.16$ & $75.76 \pm 5.41$ & $22.48 \pm 3.35$ & $41.42 \pm 2.71$ \\
\hline CP control & $81.91 \pm 7.12^{*}$ & $131.06 \pm 5.60^{*}$ & $83.62 \pm 7.40^{*}$ & $31.06 \pm 3.62^{*}$ \\
\hline CP + AEIA 200mg/kg & $62.84 \pm 4.58^{\#}$ & $87.02 \pm 3.29^{\#}$ & $36.85 \pm 2.54^{\#}$ & $37.58 \pm 2.02^{\text {ns }}$ \\
\hline CP + AEIA 400mg/kg & $55.70 \pm 4.52^{\#}$ & $78.60 \pm 4.61^{\#}$ & $25.48 \pm 4.73^{\#}$ & $41.98 \pm 2.01^{\#}$ \\
\hline
\end{tabular}

All the values are in mean $\pm \mathrm{SEM}, \mathrm{n}=5, \mathrm{~ns}=$ not significant, $* \mathrm{P}<0.05$ when compared to normal control group, ${ }^{\#} \mathrm{P}<0.05$ when compared to $\mathrm{CP}$ control group. AEIA=Aqueous extract of Ipomoea aquatica.

\section{Effects on atherogenic index (AI)}

Atherogenic index (cardiac risk ratio) was also significantly $(\mathrm{P}<0.05)$ increased in $\mathrm{CP}$ control group as compared to normal control group. AEIA treatment significantly $(\mathrm{P}<0.05)$ reduced the ratio compared to $\mathrm{CP}$ control group. High dose of the plant extracts showed higher protection percentage (Table 2).

Table 2: Comparison of atherogenic index in group wise and estimated protection percentage.

\begin{tabular}{|lll|}
\hline $\begin{array}{l}\text { Treatment } \\
\text { Atherogenic Index } \\
\text { (Cardiac risk ratio) }\end{array}$ & Protection $(\%)$ \\
\hline Normal control & 1.83 & ------ \\
\hline CP control & $4.68^{*}$ & ------ \\
\hline CP + AEIA $200 \mathrm{mg} / \mathrm{kg}$ & $2.33^{\#}$ & 50.21 \\
\hline CP + AEIA $400 \mathrm{mg} / \mathrm{kg}$ & $1.89^{\#}$ & 59.62 \\
\hline
\end{tabular}

All the values are in mean \pm SEM, $n=5, * \mathrm{P}<0.05$ when compared to normal control group, ${ }^{\#} \mathrm{P}<0.05$ when compared to $\mathrm{CP}$ control group. AEIA=Aqueous extract of Ipomoea aquatica.

\section{Histopathology of heart}

In normal control group cardiac muscle fibres were uniform in size, shape and configuration (Figure 1). CP control group showed loss of normal architecture of myocardium, necrosis and degeneration of myocardial fibres, vacuole changes and fragmentation of cardiac muscle fibres (Figure 2) compared to normal control group. Group III (CP + AEIA $200 \mathrm{mg} / \mathrm{kg}$ ) showed moderate myocardial damage with less myofibrillar degeneration (Figure 3) and group IV (CP + AEIA 400 $\mathrm{mg} / \mathrm{kg}$ ) showed near normalization of cardiac muscle fibres (Figure 4). The protection of heart tissue offered by AEIA was strongly correlated with normalization of dyslipidaemia by AEIA treatment.

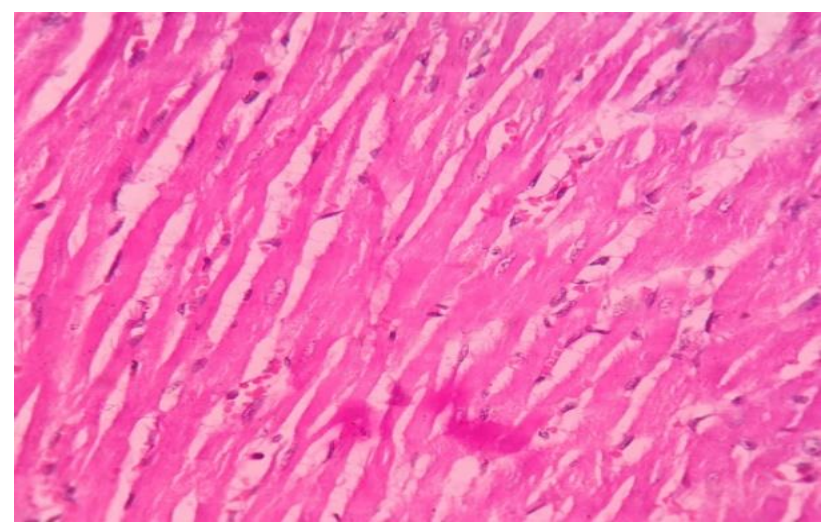

Figure 1: Histopathology ( $\mathrm{H}$ and $\mathrm{E}, 400 \mathrm{X}$ ) of normal control group showing normal texture of cell. 


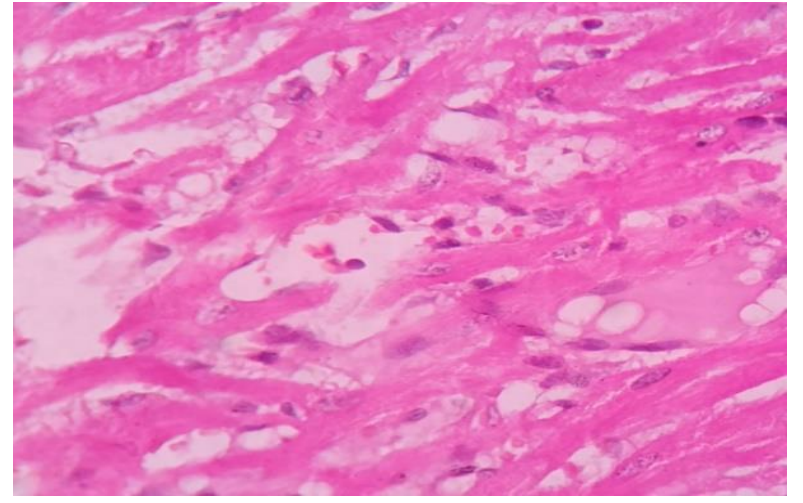

Figure 2: Histopathology ( $\mathrm{H}$ and $\mathrm{E}, 400 \mathrm{X})$ of $\mathrm{CP}$ control group showing vacuolization, degeneration, fragmentation of cardiac muscle fibres.

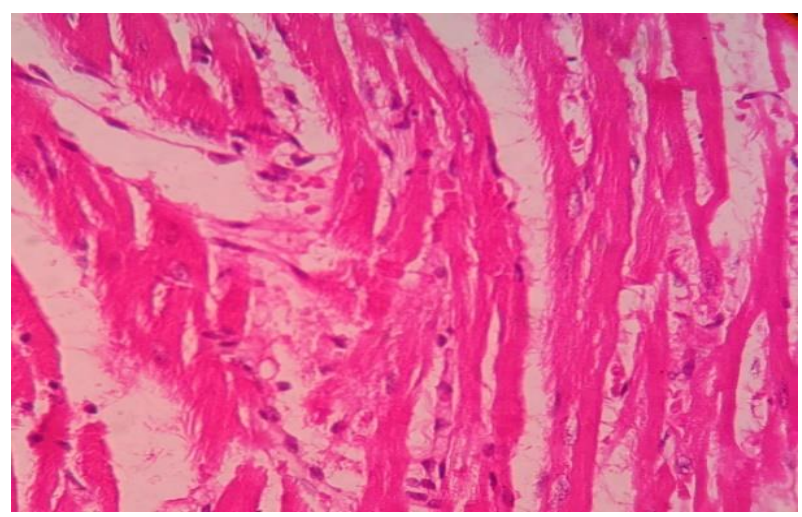

Figure 3: Histopathology ( $\mathrm{H}$ and E, 400X) of group III (CP+ AEIA 200mg/kg) showing less myofibrillar degeneration.

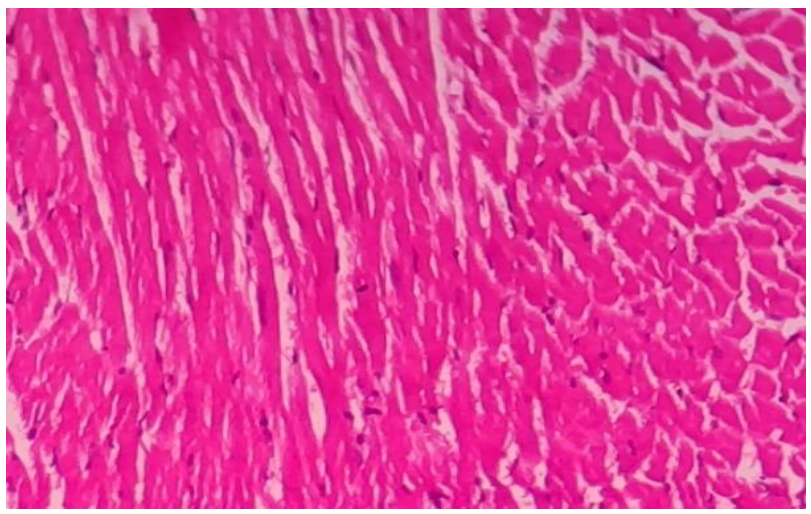

Figure 4: Histopathology (H and E, 400X) of group IV (CP+ AEIA 400mg/kg) showing near normalization of cardiac muscle fibres.

\section{DISCUSSION}

Dyslipidaemia is the presence of elevated or abnormal levels of lipids and lipoproteins, and low levels of HDLcholesterol. Serum lipids and lipoproteins abnormalities are regarded as a highly modifiable risk factor for cardiovascular diseases. ${ }^{18}$ Cyclophosphamide induces oxidative stress through its toxic metabolite acrolein. It can cause dyslipidaemia by increasing cholesterol biosynthesis, decreasing cholesteryl ester hydrolysis and reducing cholesterol efflux. So, cholesterol accumulation occurs by increase in biosynthesis and decrease in its utilization. Triglycerides are degraded by the lipoprotein lipase (LPL) to fatty acids. Alterations in LPL activity by $\mathrm{CP}$ may increase the level of triglycerides. ${ }^{19.20}$

In the study, $\mathrm{CP}$ treatment caused hypertriglyceridemia, hypercholesterolemia, increased in LDL-cholesterol level and decreased in HDL-cholesterol level resulting in dyslipidaemic changes in blood. AI or cardiac risk ratio also increased in $\mathrm{CP}$ control rats compared to normal control rats. Post treatment with AEIA after CP injection caused reduction in the elevated levels of triglycerides, total cholesterol, LDL-cholesterol and atherogenic index. There was also increased in HDL-cholesterol in AEIA treated group. Higher dose of AEIA caused more favourable changes in lipid profile. So, it proves that AEPF alleviate CP induced lipid profile derangements. In Moirangthem RS et al, study, there was similar changes in the lipid profile and atherogenic index by $\mathrm{CP}$ and treatment with plant extract reverses the changes in albino rats. ${ }^{14}$ Sivaraman D et al, in his study also found that, Ipomoea aquatica has lipid lowering activity in rats. ${ }^{21}$

In histopathology examination, $\mathrm{CP}$ caused massive change in the myocardium like necrosis, vacuolization, degeneration and fragmentation of cardiac muscle fibres. Treatment with AEIA effectively inhibits $\mathrm{CP}$ induced cardiac damage by reversal of the above changes. Protective changes in myocardium are strongly correlated with favourable changes of lipid profile by AEIA treatment. Small animals like rat are generally resistant to the development of vascular atherosclerotic changes, ${ }^{14}$ so more studies with long duration and higher animal like rabbit should be done. Swamy AHMV et al, in his study also found the similar cardiac damages by $\mathrm{CP}$ and there was reversal of the damages by plant extract treatment in rats. $^{20}$

Flavonol glycoside like 7-O- $\beta$-D-glucopyranosyldihydroquercetin-3-O- $\alpha$-D-glucopyranoside constituent of Ipomoea aquatica has potent antioxidant activity. Carotenoids like violaxanthin, lutein and $\beta$-carotene, flavonoids, tannins, poly-phenolic constituents present in the plant have antioxidant activity. Among them, flavonoids are known for their diverse activities including hypolipidemic and antioxidant activity. These phytoconstituents along with others in Ipomoea aquatica may be providing the protective effect against $\mathrm{CP}$ induced dyslipidaemia. $^{22,23}$

\section{CONCLUSION}

From the present study, it can be concluded that cyclophosphamide treatment causes dyslipidaemia and tissue damage in the myocardium. Administration of aqueous extract of leaves and stems Ipomoea aquatica 
protects the CP-induced dyslipidaemia. Biochemical and histopathological studies confirm the protective role of Ipomoea aquatica Frosk.

\section{ACKNOWLEDGEMENTS}

Authors would like to thank Professor P. K. Singh of the Life Sciences Department, Manipur University, Imphal, Manipur, India for identification of plant Ipomoea aquatica Frosk. The authors are also sincerely thankful to the management of Dept. of Pharmacology and Dept. of Pathology, RIMS, Imphal, India for their constant encouragement and support and providing all the necessary facilities for carrying out this study.

Funding: No funding sources

Conflict of interest: None declared

Ethical approval: The study was approved by the Institutional Animal Ethics Committee (1596/GO/a/12/CPCSEA)

\section{REFERENCES}

1. Chu E, Sartorelli AC. Cancer chemotherapy. In: Katzung BG, Trevor AJ, editors. Basic and clinical pharmacology. 13 ${ }^{\text {th }}$ Ed. New Delhi: McGraw-Hill Education; 2015:918-945.

2. Taghiabadi E, Imenshahidi M, Abnous K, Mosafa F, Sankian M, Bahram Memar B, et al. Protective effect of silymarin against acrolein-induced cardiotoxicity in mice. Evid Based Complement Alternat Med. 2012;2012:1-14.

3. Conklin DJ, Barski OA, Lesgards JF, Juvan P, Rezen $\mathrm{T}$, Rozman D, et al. Acrolein consumption induces systemic dyslipidemia and lipoprotein modification. Toxicol Appl Pharmacol. 2010;243(1):1-26.

4. Malakarc C, Choudhury PPN. Pharmacological potentiality and medical uses of Ipomoea aquatica Forsk: a review. Asian $\mathrm{J}$ Pharm Clin Res. 2015;8(2):60-3.

5. Manvar MN. Pharmacognostical investigations on Ipomoea aquatica Forsk. Int J Pharm Sci Res. 2011;2(11):2812-5.

6. Sinha SC. Medicinal plants of Manipur. Imphal: Mass \& Sinha; 1996.

7. Verma SCL, Agarwal SL. Studies on Leptadenia reticulata: Part II. Preliminary chemical investigations. Indian J Med Res. 1962;50:439-50.

8. OECDi Library. Fact sheet: OECD guidelines for the testing of chemicals, Section 4. Test no. 423: Acute Oral toxicity- Acute toxic class method. Available at: http://www.oecd-ilibrary.org/environment/test-no423-acute-oral-toxicity-acute-toxic-class-

method_9789264071001-en Accessed 16 August 2017.

9. Ministry of Environment, Forest and Climate Change, Government of India. Fact sheet: Committee for the Purpose of Control and Supervision of Experiments on Animals (CPCSEA). Standard Operating Procedures (SOP) for Institutional Animal Ethics Committee
(IAEC) of the CPCSEA. Available at: http://www.moef.nic.in/division/committee-purposecontrol-and-supervision-experiments-animals-cpcsea Accessed 16 August 2017.

10. Sullivan DR, Kruijswijk Z, West CE, Kohlmeier M, Katan MB. Determination of serum triglycerides by an accurate enzymatic method not affected by free glycerol. Clin Chem. 1985;31(7):1227-8.

11. Allain CC, Poon LS, Chan CS, Richmond W, Fu CP. Enzymatic determination of total serum cholesterol. Clin Chem. 1974;20:470-5.

12. Grub F, Izzo C, Mazzotti G, Murador E. Improved method for determination of high-density-lipoprotein cholesterol II. Enzymic determination of cholesterol in high-density lipoprotein fractions with a sensitive reagent. Clin Chem. 1981;27(3):375-9.

13. Ito MK. Dyslipidaemias. In: Burns MAC, Wells BG, Schwinghammer TL, Malone PM, Kolesar JM, Di Piro JT, editors. Pharmacotherapy: principles and practice. $3^{\text {rd }}$ Ed. New York: Mc Graw Hill medical; 2013:245-267.

14. Moirangthem RS, Jitendra SSV, Devi HC, Devi KS, Gunindro N, Devi NM. Effect of aqueous extract of Phyllanthus fraternus leaf against cyclophosphamide induced dyslipidemia and aortitis in wistar albino rats. Int J Cont Med Res. 2016;3(9):2703-6.

15. Grizzle WE, Fredenburgh JL, Myers RB. Fixation of tissues. In: Bancroft JD, Gamble M, editors. Theory and practice of histological techniques. $6^{\text {th }}$ Ed. Philadelphia: Churchill Livingstone; 2008:53-74.

16. Spencer LT, Bancroft JD. Microtomy: paraffin and frozen. In: Bancroft JD, Gamble M, editors. Theory and practice of histological techniques. $6^{\text {th }}$ Ed. Philadelphia: Churchill Livingstone; 2008:93-104.

17. Jones ML, Bancroft JD, Gamble M. Connective tissues and stains. In: Bancroft JD, Gamble M, editors. Theory and practice of histological techniques. $6^{\text {th }} \mathrm{Ed}$. Philadelphia: Churchill Livingstone; 2008:135-160.

18. Bersot TP. Drug therapy for hypercholesterolemia and dyslipidemia. In: Brunton LL, Chabner BA, Knollmann BC, editors. Goodman \& Gilman's The Pharmacological Basis of Therapeutics. $12^{\text {th }}$ Ed. New York: McGraw-Hill Medical; 2011:877-908.

19. Gado AM, Adam ANI, Aldahmash BA. Cardiotoxicity induced by cyclophosphamide in rats: protective effect of curcumin. J Res Environ Sci Toxicol. 2013;2(4):8795.

20. Swamy AHMV, Patel UMP, Koti BC, Gadad PC, Patel NL, Thippeswamy AHM. Cardioprotective effect of Saraca indica against cyclophosphamide induced cardiotoxicity in rats: a biochemical, electrocardiographic and histopathological study. Indian J Pharmacol. 2013;45(1):44-8.

21. Sivaraman D, Muralidaran P. Hypolipidemic activity of Ipomoea aquatica Forsk. leaf extracts on lipid profile in hyperlipidemic rats. Int J Pharm Biol Sci Arch. 2010;1(2):175-9.

22. Manvar MN, Desai TR. Phytochemical and pharmacological profile of Ipomoea aquatica. Indian J Med Sci. 2013;67(3):49-60. 
23. Prasad KN, Divakar S, Shivamurthy GR, Aradhya SM. Isolation of a free radical-scavenging antioxidant from water spinach (Ipomoea aquatica Forsk). J Sci Food Agric. 2005;85:1461-8.
Cite this article as: Das R, Khuraijam SD, Dutta S, Das A, Das P, Devi KKP. Effects of Ipomoea aquatica Forsk. in cyclophosphamide induced dyslipidaemia in albino rats. Int J Basic Clin Pharmacol 2017;6:2743-8. 